\title{
Maintenance therapy in Crohn's disease
}

\author{
Hillary Steinhart MD FRCPC
}

Steinhart H. Maintenance therapy in Crohn's disease. Can J Gastroenterol 2000;14(Suppl C):23C-28C. Symptoms of active Crohn's disease may respond to one or more of a number of classes of drug therapies. These include systemic glucocorticoids, budesonide, sulphasalazine, mesalazine (5-aminosalicylates), immunosuppressive agents and antibiotics. More recently, a chimeric mouse-human antibody to tumour necrosis factor (infliximab) has been shown to induce clinical remission and endoscopic improvement in patients with moderately active Crohn's disease refractory to other therapies. Despite this wide range of existing therapies and the potential of emerging biological therapies, recurrent Crohn's disease continues to be a major impediment to the fulfilment of a normal lifestyle and optimal quality of life for patients with Crohn's disease. Many drugs known to be effective for the treatment of active disease have been tried as maintenance therapy to prevent disease relapse or recurrence following medical or surgical therapy. The available evidence suggests that most of these drugs are not as useful in maintaining remission as they are in inducing it. Systemic glucocorticoids, budesonide, mesalazine (5-aminosalicylates), sulphasalazine and antibiotics are all associated with either marginal therapeutic gain in the setting of maintenance therapy or unacceptable long term toxicity. The immunosuppressive agents azathioprine, 6-mercaptopurine and methotrexate have been shown to have a beneficial effect in maintaining remission and may be helpful as steroid-sparing agents. Repeated infusions of antitumour necrosis factor antibody maintain the improvements observed after one or two initial infusions. The relative long term safety, efficacy and cost effectiveness of the various choices of maintenance therapy remain to be determined.

Key Words: Corticosteroids; Crohn's disease; Immunosuppression; Infliximab

\section{Traitement d'entretien de la maladie de Crohn}

RÉSUMÉ : Les symptômes de la maladie de Crohn en évolution peuvent rétrocéder sous l'action de plus d'une classe de médicaments, notamment les glucocorticoïdes à action générale, le budésonide, la sulfasalazine, la mésalazine (5-aminosalicylate), les immunosuppresseurs et les antibiotiques. Tout récemment, un anticorps chimérique souris-humain contre le facteur de nécrose des tumeurs (infliximab) a provoqué une rémission clinique et une amélioration endoscopique chez les patients atteints de la maladie de Crohn à évolution modérée, réfractaire à d'autres traitements. Malgré le large éventail de médicaments possibles et le potentiel des nouveaux traitements biologiques, la maladie de Crohn récidivante constitue toujours un obstacle majeur à un mode de vie normal et à une qualité de vie optimale pour les personnes qui en sont atteintes. De nombreux médicaments connus pour leur efficacité dans le traitement de la maladie évolutive ont été essayés comme médicaments d'entretien dans le but de prévenir une rechute ou une récurrence à la suite d'un traitement médical ou chirurgical. Les preuves actuelles semblent indiquer que la plupart de ces médicaments sont plus efficaces pour susciter une rémission que pour la maintenir. Les glucocorticoïdes à action générale, le budésonide, la mésalazine, la sulfasalazine et les antibiotiques sont tous associés à une faible amélioration thérapeutique dans le cadre d'un traitement d'entretien ou à une toxicité inacceptable à long terme. Par contre, les immunosuppresseurs comme l'azathioprine, la 6-mercaptopurine et le méthotrexate ont un effet favorable sur le maintien de la rémission et pourraient s'avérer des épargneurs de stéroïdes utiles. Des perfusions répétées d'anticorps contre le facteur de nécrose des tumeurs maintiennent les améliorations observées après la première ou la deuxième perfusion. Il reste maintenant à déterminer l'innocuité, l'efficacité et le rapport coût-efficacité relatifs à long terme des divers traitements d'entretien.
$\mathrm{D}$ espite significant advances in the understanding of the mechanisms of chronic inflammation of the gastrointestinal tract, the long term control of Crohn's disease remains a challenge for patients and their physicians. Crohn's disease follows several modes of disease activity based on its natural history. An individual may have acute relapsing Crohn's disease, chronically active Crohn's disease or quiescent Crohn's disease. This somewhat artificial division may

Department of Medicine, Mount Sinai Hospital, University of Toronto, Toronto, Ontario

Correspondence: Dr A Hillary Steinhart, Mount Sinai Hospital, Room 445, 600 University Avenue, Toronto, Ontario M5G 1X5. Telephone

416-586-5121, fax 416-586-3174, e-mail hsteinhart@mtsinai.on.ca 


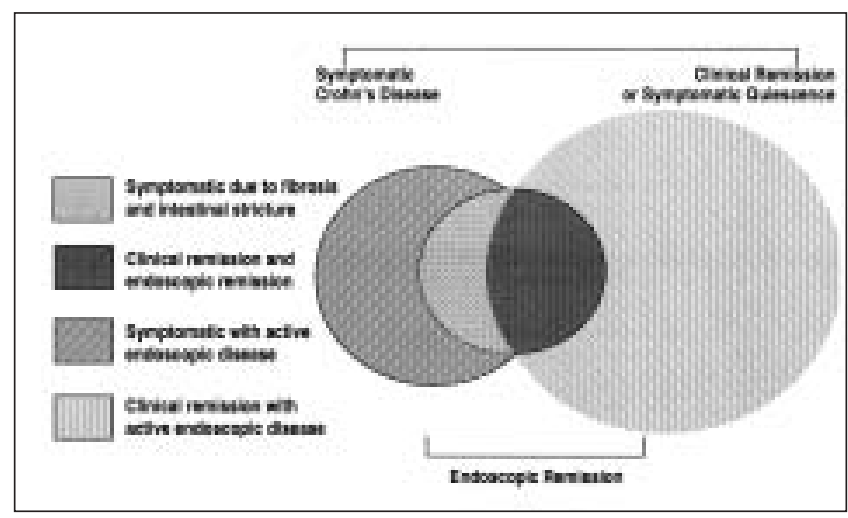

Figure 1) Schematic representation of the clinical and endoscopic status of the population of patients with Crohn's disease excluding those with perianal fistulizing disease. Patients may be in one of several states: symptomatic due to intestinal fibrosis and stricture without evidence of endoscopic disease activity, clinical remission without evidence of endoscopic disease activity, symptomatic with evidence of endoscopic disease activity and clinical remission with evidence of endoscopic disease activity

be difficult to define for the purposes of clinical studies, but physicians usually have a global sense of what each of these categories represents.

The goal of maintenance therapy usually is to keep patients in the quiescent state for as long as possible, with minimum drug toxicity. Ideally, maintenance therapy should also maximize quality of life. Although there are numerous clinical trials of maintenance therapy in the literature, it is often difficult to make conclusions regarding the ability of the therapies to achieve the stated goals. Much of this difficulty is related to varying definitions of 'treatment success' or 'maintenance of remission'. Studies often define the efficacy of a given therapy as maintaining an index of disease activity below a predetermined value. A Crohn's disease activity index (CDAI) score of less than 150 has been the benchmark used to define 'clinical remission' or 'clinical quiescence' by most studies (1-8). Despite the fact that the CDAI has been used for over 20 years and has been previously validated, it has certain deficiencies and is somewhat cumbersome to use. Other definitions of remission include the need for additional medical or surgical therapy, maintenance of a certain patient quality-of-life score and the degree of endoscopic or histological disease activity.

There is often a dichotomy between the clinical disease activity and the presence of endoscopic disease $(9,10)$. Modigliani and co-workers (9) showed that, although $92 \%$ of patients with Crohn's disease treated with high-dose glucocorticoids achieved clinical remission (CDAI score of less than 150), the endoscopically observed lesions healed in only $29 \%$. This means that the majority of patients who are successfully treated with medical therapy for the acute symptoms of Crohn's disease, as evaluated by conventional clinical criteria, continue to have intestinal inflammation that is visible with the colonoscope, even after symptoms have subsided (Figure 1). This observation indicates a need for chronic maintenance therapy in most patients whose
TABLE 1

Goals of maintenance therapy for Crohn's disease

Reduce frequency of recurrent symptoms

Reduce severity of recurrent symptoms

Avoid disease-related complications

Avoid treatment-related complications

Heal intestinal mucosa

Maintain optimal nutritional status

Maximize health-related quality of life

Crohn's disease is in clinical remission as defined by conventional clinical criteria. Although successful maintenance therapy may appear to prolong clinical remission, in the majority of patients it may simply provide ongoing, active treatment of the residual endoscopic and histological disease activity. Whether maintenance therapy beneficially alters the overall natural history of the disease is not known, despite the fact that some maintenance therapies appear to reduce the risk of clinical relapse or prolong the duration of clinical remission. Ideally, the goals of any successful maintenance therapy should include some or all of the following aspects: reduction in the frequency and severity of recurrent symptoms, maintenance of optimal nutritional status, avoidance of disease- and treatment-related complications, healing of the intestinal mucosa and maintenance of optimal health-related quality of life (Table 1 ).

\section{CONVENTIONAL GLUCOCORTICOIDS}

Conventional glucocorticoids such as prednisone, prednisolone and methylprednisolone have been shown to be highly effective in treating the acute symptoms of Crohn's disease flares $(5,8,9)$. Remission can be achieved with a course of oral glucocorticoids in $60 \%$ to $92 \%$ of patients, but for the majority of patients, continuous low dose glucocorticoid therapy does not improve clinical remission rates over one to two years $(5,8,11,12)$. However, closer evaluation of the results of the European and National Cooperative Crohn's Disease Studies $(5,8)$ suggests that there may be a subset of patients with Crohn's disease who, after responding to an initial course of high dose glucocorticoid therapy, are more likely to remain in remission if the glucocorticoid therapy is continued at a low dose. Chronic glucocorticoid therapy can result in significant cosmetic, psychiatric, metabolic and bone-related side effects and complications, and its use over extended periods of time has generally been disfavoured by many physicians and not accepted by patients (13). Nevertheless, in a few patients, the use of low dose glucocorticoids can be considered. Typically, this would be a patient in whom multiple attempts at glucocorticoid weaning have been unsuccessful, in whom a relatively low dose of prednisone (10 to $15 \mathrm{mg} /$ day) adequately controls disease symptoms and in whom there are no significant adverse effects at 
the dose required to control symptoms. Other steroidsparing strategies should have been tried or offered to the patient before embarking on chronic glucocorticoid therapy. If chronic glucocorticoid therapy is used, careful monitoring for long term sequelae is mandatory.

\section{BUDESONIDE}

The controlled ileal release form of budesonide, an effective form of therapy for active Crohn's disease, was evaluated as a potential and safer maintenance therapy than conventional glucocorticoids. Unfortunately, the results of clinical trials have not been impressive $(3,4,14)$. Although the safety profile of budesonide 3 and $6 \mathrm{mg} /$ day was quite favourable, only the $6 \mathrm{mg} /$ day dose was able to marginally prolong the mean time until relapse, and it provided no overall remission maintenance advantage after one year of therapy. It is not known whether chronic, continuous therapy with the higher active dosage of budesonide ( $9 \mathrm{mg} /$ day) is effective or safe. However, a dosage of $9 \mathrm{mg} /$ day demonstrates evidence of a systemic glucocorticoid effect based on the appearance of a measurable inhibition of adrenal responsiveness (15). In patients whose acute symptoms of Crohn's disease respond to budesonide $9 \mathrm{mg} /$ day, it seems reasonable to maintain them on a dosage of $6 \mathrm{mg} /$ day. However, physicians should be ready to increase the dosage to $9 \mathrm{mg} /$ day if disease symptoms recur.

\section{MESALAZINE (5-AMINOSALICYLATES)}

Although mesalazine's good tolerability and excellent safety record make it an attractive choice for long term maintenance therapy, its efficacy in maintaining remission in Crohn's disease is, at best, questionable. Some clinical trials have suggested that mesalazine may be effective in certain subgroups of patients (eg, those in remission for only a short period of time), while others have shown that, overall, the treatment effect observed with mesalazine in patients with medically induced remission is minimal and not statistically significant (16-26). In patients who required glucocorticoids to control acute symptoms of Crohn's disease, mesalazine $4 \mathrm{~g} /$ day appeared to offer no therapeutic advantage over placebo (6).

\section{AZATHIOPRINE AND 6-MERCAPTOPURINE}

Immunomodulatory drugs are becoming increasingly popular as maintenance therapies for patients with Crohn's disease. Long term safety data are accumulating for these drugs, and efficacy has been consistently seen in clinical trials (2,27-29). Although all of the trials of azathioprine and 6-mercaptopurine have suffered from significant methodological deficiencies, there is sufficient consistency among the results to suggest that there is likely a true treatment effect. In a meta-analysis of five placebo controlled trials of azathioprine maintenance therapy involving 319 patients, Pearson and colleagues (30) calculated an odds ratio of 2.19 for maintenance of remission in patients receiving azathioprine. This demonstration of effectiveness is strengthened by the dose response that was observed in the meta-analysis. Preliminary evidence suggests that 6-mercaptopurine, the active metabolite of azathioprine, may reduce the risk of endoscopic and clinical relapse after surgical resection for Crohn's disease (31).

\section{METHOTREXATE}

Methotrexate is effective in the treatment of patients with chronically active, steroid-dependent Crohn's disease when given as weekly intramuscular injections of $25 \mathrm{mg}$ (32). Although many physicians find that patients who respond acutely to methotrexate appear to do well when the drug is continued as maintenance therapy, there has been no controlled trial evidence to support this impression until recently. The results of the follow-up maintenance phase of the North American Crohn's Study Group methotrexate trial (33) confirm the clinical impression of many physicians. In the maintenance study, weekly intramuscular injections of $15 \mathrm{mg}$ of methotrexate were compared with placebo injections in patients who had responded to an initial acute course of methotrexate. Sixty-five per cent of the methotrexate-treated patients maintained remission over the 48-week study period, compared with $39 \%$ of the placebo-treated patients. The steroid-sparing effect was even more significant. No additional steroid therapy was required in $72 \%$ of the methotrexate-treated patients, but only $42 \%$ of the placebo-treated patients remained steroid-free. Methotrexate appeared to be well tolerated at the $15 \mathrm{mg}$ maintenance dose and was not associated with significant toxicity. Given these results, the frequency of use of methotrexate as maintenance therapy for Crohn's disease is likely to increase in the near future.

\section{ANTIBIOTICS}

The role of antibiotics in the management of Crohn's disease is controversial. Antibiotics are used by many physicians, particularly to treat acute septic complications of Crohn's disease. However, the evidence supporting the effectiveness of antibiotics - in most studies metronidazole - in ameliorating the symptoms of acute disease activity is not conclusive (34-37). There have been no controlled trials of antibiotics for the maintenance of medically induced remissions.

In an open series, 72 patients were treated with a combination of ciprofloxacin and metronidazole for symptoms of active Crohn's disease (38). Of the 55 patients who responded, 15 were maintained on chronic combination antibiotic therapy for a mean follow-up of nine months. Of these 15 patients, $12(80 \%)$ remained in remission for the duration of follow-up. In comparison, 26 of $40(65 \%)$ patients who elected to stop antibiotics remained in remission. Rutgeerts et al (39) examined the role of antibiotics in preventing or delaying the appearance of postoperative endoscopic and clinical recurrence. They found that metronidazole $20 \mathrm{mg} / \mathrm{kg}$ daily for three months after resection reduced the severity of recurrent endoscopic lesions and appeared to reduce or delay clinical recurrence, although the latter did not achieve statistical significance. These results are suggestive, and further studies examining alternative antibiotics, dosing schedules and duration of therapy need to be conducted. 


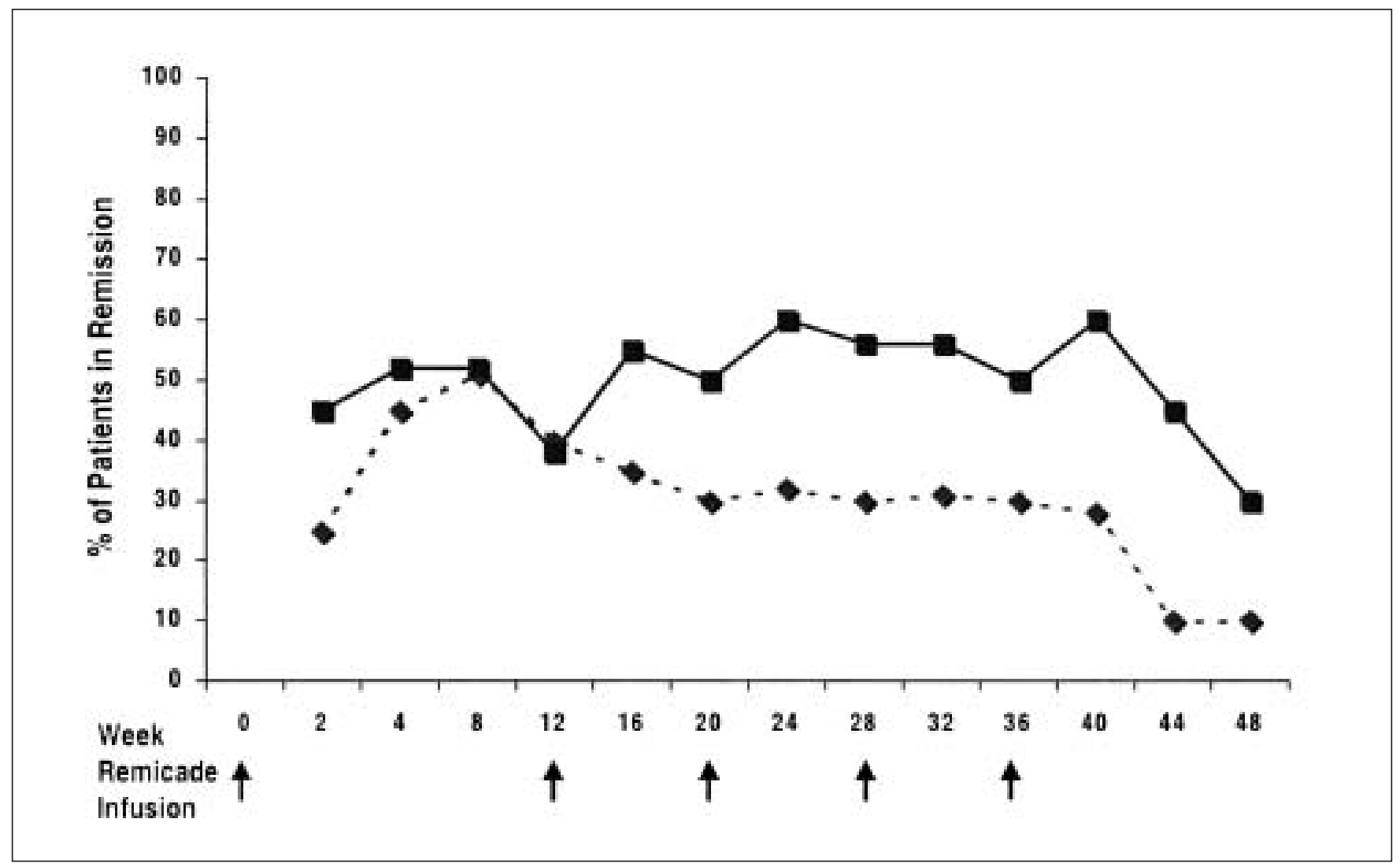

Figure 2) Proportion of patients in clinical remission during repeated infusions of infliximab (Remicade, Centocor, USA) (ロ) or placebo ( $\bullet$ ). All patients improved after receiving one or two initial infusions of Remicade for symptoms of moderate to severely active Crohn's disease. Reproduced with permission from reference 7

\section{ANTITUMOUR NECROSIS FACTOR- $\alpha$ ANTIBODIES}

The importance of tumour necrosis factor (TNF) - in the pathogenesis of intestinal inflammation in Crohn's disease is shown by the high response rate seen when the humanmouse chimeric anti-TNF- antibody, known as infliximab (Remicade, Centocor, USA) is used to treat patients who are not responsive to conventional therapies $(40,41)$. Response rates of up to $81 \%$ were seen with a single intravenous infusion of $5 \mathrm{mg} / \mathrm{kg}$ in patients with intestinal disease activity. Up to $68 \%$ of patients with fistulizing Crohn's disease responded to three infusions of infliximab $5 \mathrm{mg} / \mathrm{kg}$. Remission or complete responses were seen in $48 \%$ and $55 \%$ of patients with intestinal disease activity and fistulizing disease, respectively. Improvements in endoscopic disease activity, particularly in the right colon and rectum, were observed in a subset of patients (42). No maintenance data are available for patients with fistulizing disease, and the reported median three-month duration of response suggests that some form of maintenance strategy is required for patients with fistulizing disease to maintain a response.

For patients with intestinal disease activity, repeated infusions of infliximab, given every eight weeks, maintain the improvement observed after one or two initial infusions (7). In the retreatment study, 73 patients who had responded to an initial infusion of infliximab received either infliximab
$10 \mathrm{mg} / \mathrm{kg}$ or placebo infusions beginning 12 weeks after the initial infusion for active disease. Four additional infusions of infliximab or placebo were given at eight-week intervals, and patients were followed-up for 10 weeks after the final infusion. Infliximab improved disease activity when assessed by CDAI scores, disease-related quality-of-life scores and serum C-reactive protein concentrations. In addition, the proportion of patients in remission increased from $37.8 \%$ at the start of retreatment to $60 \%$ during the retreatment phase. In those who received placebo infusions, the proportion in remission fell from $44.4 \%$ before retreatment to $35 \%$ during retreatment (Figure 2).

Many issues need to be settled regarding the role and appropriate use of infliximab for maintenance therapy in patients with Crohn's disease. The optimal dose has not been determined. Unfortunately, only the $10 \mathrm{mg} / \mathrm{kg}$ dose was studied in the retreatment trial; this dose was different from the $5 \mathrm{mg} / \mathrm{kg}$ dose that was found to be most effective in the acute trials, and for which the drug currently is indicated for use in the United States and Europe. It is not known whether the $5 \mathrm{mg} / \mathrm{kg}$ dose is as effective as - or perhaps, more effective than - the $10 \mathrm{mg} / \mathrm{kg}$ dose. It is important to know whether retreatment needs to be given every eight weeks or whether it can be given 'on demand' according to patients' symptoms, and also whether retreatment needs to be continued beyond the four doses reported by Rutgeerts et al (7). 
The efficacy of infliximab maintenance therapy in patients with healed fistulae is also unknown.

Because of infliximab's high cost, patients, third-party payers and society will be interested in its cost effectiveness relative to existing medical and surgical therapies. Economic analyses have suggested that the major determinant of total cost of health care for patients with Crohn's disease is inpatient costs $(43,44)$. The cost of infliximab may be offset by the savings realized through reductions in hospital and surgical care.

Although experience with the use of infliximab is accumulating, concerns regarding its long term safety remain. Lymphoma has been reported in patients treated with infliximab. In the retreatment trial by Rutgeerts et al (7), one patient who was treated with a single initial infusion of infliximab and placebo retreatments developed a B-cell lymphoma 9.5 months after the initial infusion. In a much larger retreatment study of infliximab in 428 patients with rheumatoid arthritis, one B-cell lymphoma, one recurrent breast cancer and one melanoma were observed in infliximabtreated patients (45). The observed number of malignancies was calculated to be the same as the expected number based on an age- and sex-matched cohort of the general population. Notwithstanding this conclusion, the long term safety of infliximab remains to be more definitively established. Ongoing monitoring and postmarketing surveillance are required to gain a better understanding of the chronic or intermittent use of infliximab.

Another issue that needs to be studied further is the role of cotherapy with other immunomodulatory drugs. There is evidence from patients with infliximab-treated rheumatoid arthritis that the concomitant administration of methotrexate can reduce the immunogenicity of infliximab and improve efficacy $(46,47)$. Some of these issues should be addressed by studies currently in progress or by those planned for the near future.

A second anti-TNF antibody, CDP571, is a humanized monoclonal antibody currently in development for the treatment of Crohn's disease. A large clinical trial has shown its efficacy in patients with Crohn's disease refractory to other therapies (48). In that study, two or three infusions of the antibody were better than placebo infusions at

\section{REFERENCES}

1. Best WR, Becktel JM, Singleton JW, Kern F Jr. Development of a Crohn's disease activity index. National Cooperative Crohn's Disease Study. Gastroenterology 1976;70:439-44.

2. Candy S, Wright J, Gerber M, Adams G, Gerig M, Goodman R. A controlled double blind study of azathioprine in the management of Crohn's disease. Gut 1995;37:674-8.

3. Greenberg GR, Feagan BG, Martin F, et al. Oral budesonide as maintenance treatment for Crohn's disease: a placebo-controlled, dose-ranging study. Canadian Inflammatory Bowel Disease Study Group. Gastroenterology 1996;110:45-51.

4. Lofberg R, Rutgeerts $\mathrm{P}$, Malchow $\mathrm{H}$, et al. Budesonide prolongs time to relapse in ileal and ileocaecal Crohn's disease. A placebo controlled one year study. Gut 1996;39:82-6.

5. Malchow H, Ewe K, Brandes JW, et al. European Cooperative Crohn's Disease Study (ECCDS): results of drug treatment. Gastroenterology 1984;86:249-66.
TABLE 2

Possible maintenance therapies for Crohn's disease with ratings of the strength of the evidence in support of their use and the strength of the treatment effect observed in clinical trials

\begin{tabular}{lc}
\hline Maintenance therapy & $\begin{array}{c}\text { Strength of } \\
\text { evidence and effect }\end{array}$ \\
\hline Conventional glucocorticoids & $+/-$ \\
Budesonide & + \\
Mesalazine & $+/-$ \\
Azathioprine and 6-mercaptopurine & ++ \\
Methotrexate & ++ \\
Antibiotics & - \\
Infliximab & ++ \\
\hline
\end{tabular}

- No evidence of treatment effect or evidence of no effect; +/- Questionable evidence of treatment effect; + Fair evidence of treatment effect or evidence of only modest effect; + + Good evidence of treatment effect

achieving and maintaining clinical improvement over 24 weeks. A smaller, short term maintenance study involving 71 patients in remission on steroid therapy was also reported (49). Patients were randomly assigned to receive either placebo infusions or CDP571 $20 \mathrm{mg} / \mathrm{kg}$ at week 0 and $10 \mathrm{mg} / \mathrm{kg}$ at week 8 . Steroid doses were tapered by week 10 and patients were followed-up for 16 weeks. Twenty-two per cent of the placebo-treated patients remained in remission at the end of follow-up, compared with $44 \%$ of the CDP571-treated patients.

\section{SUMMARY}

Several options are available for maintenance therapy of Crohn's disease (Table 2). The choice of which therapy to use in an individual patient should depend on the disease complications, the patient's previous response to therapy, the relative long term safety record of the available choices, the relative therapy efficacy and cost. In the absence of direct comparative data among the various choices, physicians and patients must make decisions based on the available evidence in the literature, and on personal preference and experience.
6. Modigliani R, Colombel JF, Dupas JL, et al. Mesalamine in Crohn's disease with steroid-induced remission: effect on steroid withdrawal and remission maintenance, Groupe d'Etudes Therapeutiques des Affections Inflammatoires Digestives. Gastroenterology 1996;110:688-93.

7. Rutgeerts P, D'Haens G, Targan S, et al. Efficacy and safety of retreatment with anti-tumor necrosis factor antibody (infliximab) to maintain remission in Crohn's disease. Gastroenterology 1999;117:761-9.

8. Summers RW, Switz DM, Sessions JT Jr, et al. National Cooperative Crohn's Disease Study: results of drug treatment. Gastroenterology 1979;77:847-69.

9. Modigliani R, Mary JY, Simon JF, et al. Clinical, biological, and endoscopic picture of attacks of Crohn's disease. Evolution on prednisolone. Groupe d'Etude Therapeutique des Affections Inflammatoires Digestives. Gastroenterology 1990;98:811-8. 
10. Olaison G, Sjodahl R, Tagesson C. Glucocorticoid treatment in ileal Crohn's disease: relief of symptoms but not of endoscopically viewed inflammation. Gut 1990;31:325-8.

11. Smith RC, Rhodes J, Heatley RV, et al. Low dose steroids and clinical relapse in Crohn's disease: a controlled trial. Gut 1978;19:606-10.

12. Steinhart AH, Ewe K, Griffiths AM, Modigliani R, Thomsen OO. Corticosteroids for maintaining remission of Crohn's disease. In: The Cochrane Library Issue 1. Oxford: Update Software, 2000.

13. Singleton JW, Law DH, Kelley ML Jr, Mekhjian HS, Sturdevant RA. National Cooperative Crohn's Disease Study: adverse reactions to study drugs. Gastroenterology 1979;77:870-82.

14. Ferguson A, Campieri M, Doe W, Persson T, Nygard G. Oral budesonide as maintenance therapy in Crohn's disease - results of a 12-month study. Global Budesonide Study Group. Aliment Pharmacol Ther 1998;12:175-83.

15. Greenberg GR, Feagan BG, Martin F, et al. Oral budesonide for active Crohn's disease. Canadian Inflammatory Bowel Disease Study Group. N Engl J Med 1994;331:836-41.

16. Arber N, Odes SH, Fireman Z, et al. A controlled double blind multicenter study of the effectiveness of 5-aminosalicylic acid in patients with Crohn's disease in remission. J Clin Gastroenterol 1995;20:203-6. (Abst)

17. Bondesen S, and the Danish 5-ASA-group. Mesalazine (Pentasa) as prophylaxis in Crohn's disease. A multicenter, controlled trial. Scand J Gastroenterol 1991;26(Suppl 183):F44. (Abst)

18. Bresci G, Parisi G, Banti S. Long-term therapy with 5-aminosalicylic acid in Crohn's disease: is it useful? Our four years experience. Int J Clin Pharmacol Res 1994;14:133-8.

19. Brignola C, Iannone P, Pasquali S, et al. Placebo-controlled trial of oral 5-ASA in relapse prevention of Crohn's disease. Dig Dis Sci 1992;37:29-32.

20. Camma C, Giunta M, Rosselli M, Cottone M. Mesalamine in the maintenance treatment of Crohn's disease: a meta-analysis adjusted for confounding variables. Gastroenterology 1997;113:1465-73.

21. de Franchis R, Omodei P, Ranzi T, et al. Controlled trial of oral 5-aminosalicylic acid for the prevention of early relapse in Crohn's disease. Aliment Pharmacol Ther 1997;11:845-52.

22. Gendre JP, Mary JY, Florent C, et al. Oral mesalamine (Pentasa) as maintenance treatment in Crohn's disease: a multicenter placebo-controlled study. The Groupe d'Etudes Therapeutiques des Affections Inflammatoires Digestives. Gastroenterology 1993;104:435-9.

23. Prantera C, Pallone F, Brunetti G, Cottone M, Miglioli M. Oral 5-aminosalicylic acid (Asacol) in the maintenance treatment of Crohn's disease. The Italian IBD Study Group. Gastroenterology 1992;103:363-8.

24. Steinhart AH, Hemphill D, Greenberg GR. Sulfasalazine and mesalazine for the maintenance therapy of Crohn's disease: a meta-analysis. Am J Gastroenterol 1994;89:2116-24.

25. Sutherland LR, Martin F, Bailey RJ, et al. A randomized, placebo-controlled, double-blind trial of mesalamine in the maintenance of remission of Crohn's disease. The Canadian Mesalamine for Remission of Crohn's Disease Study Group. Gastroenterology 1997;112:1069-77.

26. Thomson AB, Wright JP, Vatn M, et al. Mesalazine (Mesasal/Claversal) $1.5 \mathrm{~g}$ b.d. vs. placebo in the maintenance of remission of patients with Crohn's disease. Aliment Pharmacol Ther 1995;9:673-83.

27. Markowitz J, Rancher KG, Kohn N, Daum F. The multicenter pediatric Crohn's disease 6-mercaptopurine trial. Final results. Gastroenterology 1999;116:A771. (Abst)

28. O'Donoghue DP, Dawson AM, Powell-Tuck J, Bown RL, Lennard-Jones JE. Double-blind withdrawal trial of azathioprine as maintenance treatment for Crohn's disease. Lancet 1978;ii:955-7.

29. Present DH, Korelitz BI, Wisch N, Glass JL, Sachar DB, Pasternack BS. Treatment of Crohn's disease with 6-mercaptopurine. A long-term, randomized, double-blind study. N Engl J Med 1980;302:981-7.

30. Pearson DC, May GR, Fick G, Sutherland LR. Azathioprine for maintaining remission of Crohn's disease. In: The Cochrane Library Issue 1. Oxford: Update Software, 2000.

31. Korelitz B, Hanauer S, Rutgeerts P, Present D, Peppercorn M. Post-operative prophylaxis with 6-MP, 5-ASA or placebo in Crohn's disease. A 2 year multicenter trial. Gastroenterology 1999;114:A1011. (Abst)

32. Feagan BG, Rochon J, Fedorak RN, et al. Methotrexate for the treatment of Crohn's disease. The North American Crohn's Study Group Investigators. N Engl J Med 1995;332:292-7.

33. Feagan B, McDonald J, Hopkins M, Wong C, Koval J. A randomized controlled trial of methotrexate (MTX) as a maintenance therapy for chronically active Crohn's disease. Gut 1999;45:A131. (Abst)

34. Colombel JF, Lemann M, Cassagnou M, et al. A controlled trial comparing ciprofloxacin with mesalazine for the treatment of active Crohn's disease. Groupe d'Etudes Therapeutiques des Affections Inflammatoires Digestives (GETAID). Am J Gastroenterol 1999;94:674-8.

35. Prantera C, Zannoni F, Scribano ML, et al. An antibiotic regimen for the treatment of active Crohn's disease: a randomized, controlled clinical trial of metronidazole plus ciprofloxacin. Am J Gastroenterol 1996;91:328-32.

36. Sutherland L, Singleton J, Sessions J, et al. Double blind, placebo controlled trial of metronidazole in Crohn's disease. Gut 1991;32:1071-5.

37. Ursing B, Alm T, Barany F, et al. A comparative study of metronidazole and sulfasalazine for active Crohn's disease: the cooperative Crohn's disease study in Sweden. II. Result. Gastroenterology 1982;83:550-62.

38. Greenbloom SL, Steinhart AH, Greenberg GR. Combination ciprofloxacin and metronidazole for active Crohn's disease. Can J Gastroenterol 1998;12:53-6.

39. Rutgeerts P, Hiele M, Geboes K, et al. Controlled trial of metronidazole treatment for prevention of Crohn's recurrence after ileal resection. Gastroenterology 1995;108:1617-21.

40. Present DH, Rutgeerts P, Targan S, et al. Infliximab for the treatment of fistulas in patients with Crohn's disease. N Engl J Med 1999;340:1398-405.

41. Targan SR, Hanauer SB, van Deventer SJ, et al. A short-term study of chimeric monoclonal antibody cA2 to tumor necrosis factor alpha for Crohn's disease. Crohn's Disease cA2 Study Group. N Engl J Med 1997;337:1029-35.

42. D'haens G, Van Deventer S, Van Hogezand R, et al. Endoscopic and histological healing with infliximab anti-tumor necrosis factor antibodies in Crohn's disease: A European multicenter trial. Gastroenterology 1999;116:1029-34.

43. Feagan BG, Larson LR, Vreeland MG, Bala MV. Annual cost of care for Crohn's disease. Gastroenterology 1999;116:A57. (Abst)

44. Hay AR, Hay JW. Inflammatory bowel disease: medical cost algorithms. J Clin Gastroenterol 1992;14:318-27.

45. Schaible TF, Braakman T, Marteau P, Harriman G. Long-term safety of infliximab (anti-TNF- antibody) in patients with rheumatoid arthritis: results of the ATTRACT trial. Gastroenterology 1999;116:A813. (Abst)

46. Antoni C, Kalden JR. Combination therapy of the chimeric monoclonal anti-tumor necrosis factor alpha antibody (infliximab) with methotrexate in patients with rheumatoid arthritis. Clin Exp Rheumatol 1999;17(Suppl 18):S73-7.

47. Maini RN, Breedveld FC, Kalden JR, et al. Therapeutic efficacy of multiple intravenous infusions of anti-tumor necrosis factor alpha monoclonal antibody combined with low-dose weekly methotrexate in rheumatoid arthritis. Arthritis Rheum 1998;41:1552-63.

48. Sandborn WJ, Targan SR, Wolf DC, et al. A randomized, double-blind, placebo-controlled, multi-center trial of the engineered human antibody to TNF (CDP571) for induction and maintenance of clinical improvement in patients with moderate to severely active Crohn's disease. Gut 1999;45:A133. (Abst)

49. Feagan BG, Sandborn WJ, Baker JP, et al. A randomized, double-blind, placebo-controlled, multi-center trial of the engineered human antibody to TNF (CDP571) for steroid sparing and 


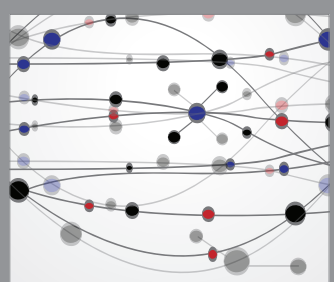

The Scientific World Journal
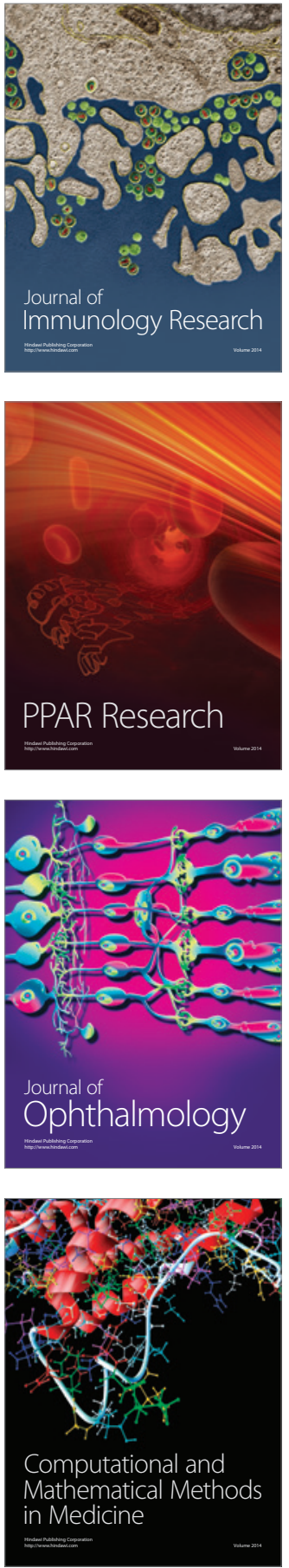

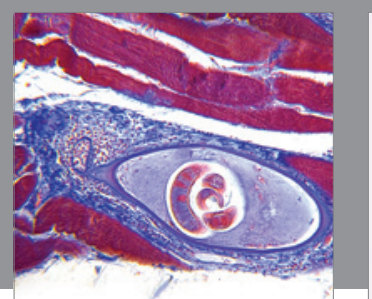

Gastroenterology Research and Practice

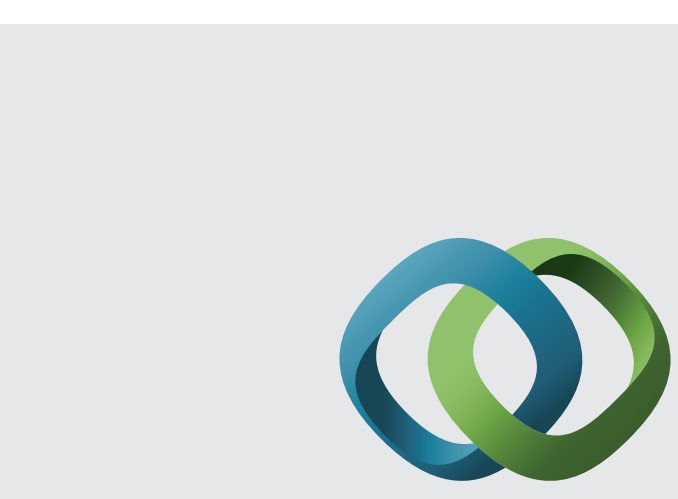

\section{Hindawi}

Submit your manuscripts at

http://www.hindawi.com
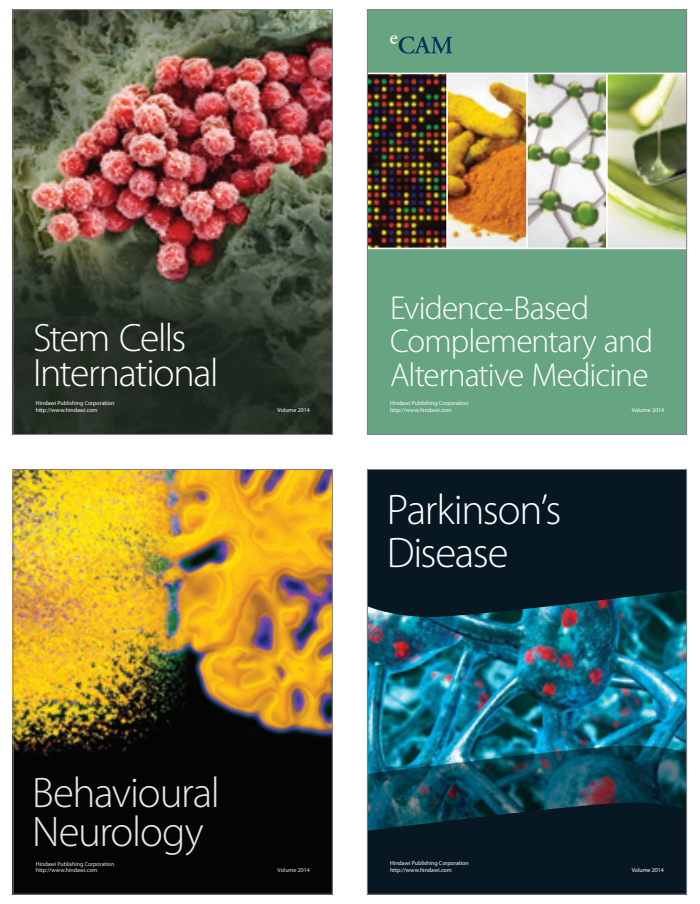
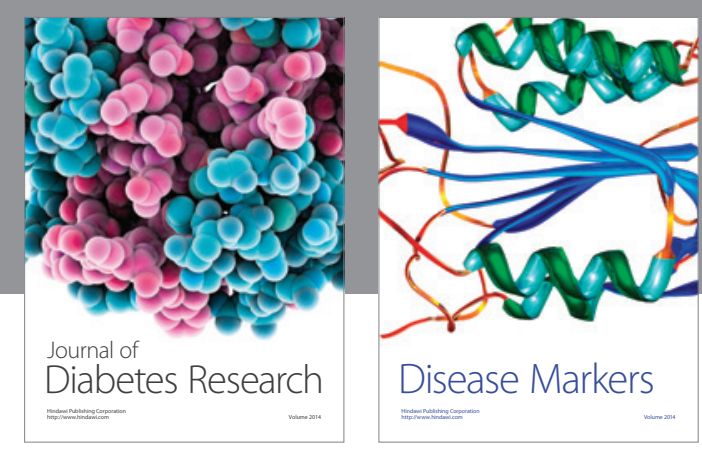

Disease Markers
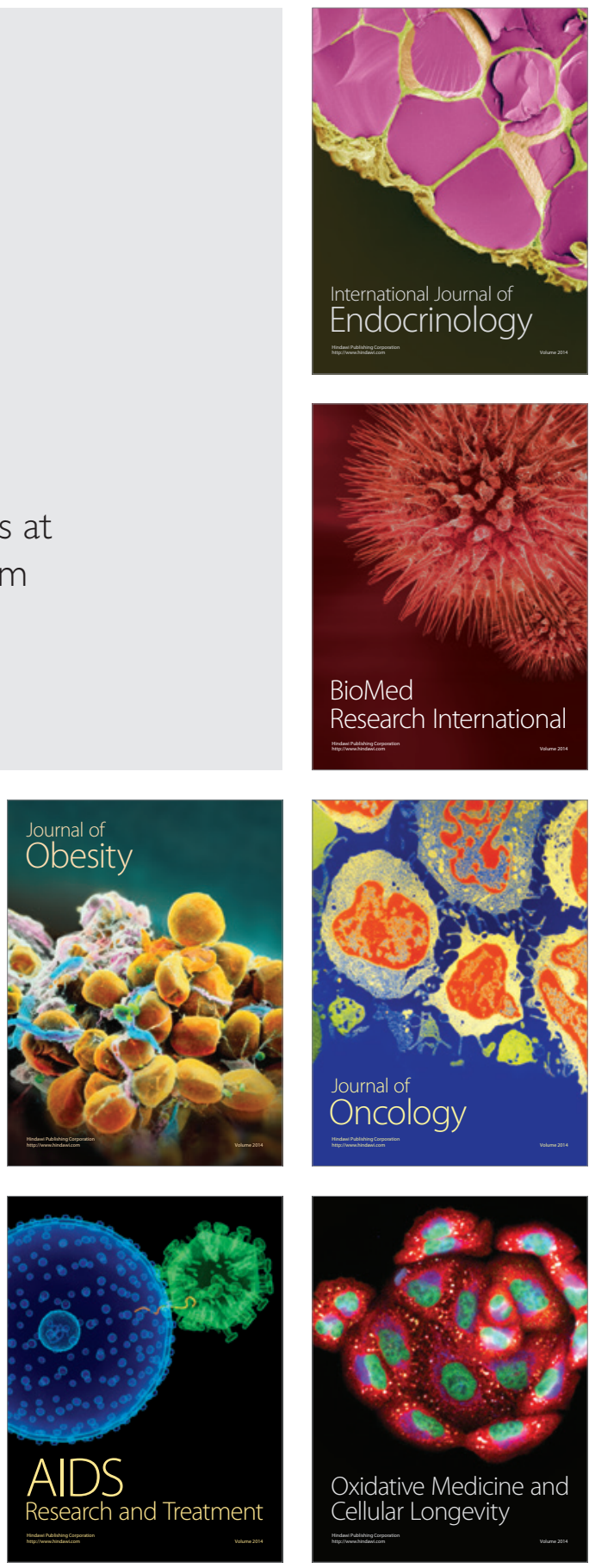